\title{
СУЧАСНЕ ЕСТРАДНЕ ВОКАЛЬНЕ ВИКОНАВСТВО У ВИМІРАХ ПРИНЦИПУ КУЛЬТУРОВІДПОВІДНОСТІ
}

\author{
Кулага Т. О., Сегеда Н. А.
}

\section{ВСТУП}

Розвиток масових комунікацій та розширення інформаційного середовища сприяє глобалізації культури та детермінує формування нової пізнавальної парадигми, яка заснована на спілкуванні між безліччю різних культур, спілкуванні з усім світом, коли ставиться сама проблема культури, і цей стан, «не відчужуючись і не переходячи в інший стан, проявляється в науковому інтересі до всіх інших культур і в готовності їх зрозуміти» ${ }^{1}$. Процеси інтеграції в музичному мистецтві почались ще на початку XX століття, а на цей час синергія різних культур стала майже всеосяжною.

Різні аспекти культури та музичного мистецтва XX-XXI століть розглядались такими вченими, як Т. Адорно, Б. Асаф'єв, В. Бичков, К. Ван Мальсен, А. Васюріна, М. Каган, І. Кондаков, Е. Левінас, М. Лобанова, Л. Мазель, Н. Маньковська, В. Медушевський, А. Папеніна, О. Соколов, А. Сохор, В. Холопова, В. Черняк, Н. Щербакова та інші.

Мистецтво естради загалом й естрадне вокальне мистецтво зокрема як феномен сучасності розглядають О. Бойко, В. Конен, Ж. Ло Ветрі, М. Мозговий, Є. М'якотін, Н. Онищук, В. Откидач, Т. Самая, Ю. Сетдікова, О. Сметана, В. Тормахова тощо.

Питання вокального естрадно-джазового виконавства науково розробляються Е. Бонацці, Л. Крістіансен, П. Грегом, Л. Лайонс, В. Сін, Н. Дрожжиною, Л. Каменецькою, Д. Каток, К. Кішімото, Л. Красовською, Р. Лебон, Т. Снайдер, Л. Сьоміною, Р. Едвіном, Е. Едіссон тощо.

Але слід зазначити, що при тому, що у світі $є$ певна кількість культурологічних та мистецтвознавчих досліджень 3 питань некласичного вокального виконавства, вітчизняна естрадна вокальна педагогіка базується більшою мірою на класичній вокальній традиції та не відповідає цивілізаційним викликам сучасної музичної культури.

Мета статті - окреслити особливості сучасного естрадного вокального виконавства у контексті актуалізації принципу культуровідповідності.

\section{1. Генезис сучасного естрадного мистецтва}

Сутність музичного мистецтва філософами розглядається по-різному i знаходиться в тісному взаємозв'язку із загально філософськими тенденціями кожного історичного періоду.

\footnotetext{
${ }^{1}$ Левинас Э. Философское определение идеи культуры. Москва : Прогресс, 1990. С. 87.
} 
Відсутність чіткої однозначної термінології естрадного мистецтва у світовій і вітчизняній науці призводить до наявності різних понять, які його характеризують, наприклад, «популярна музика», «легка музика», «комерційна музика», «масова музика», «некласична музика», «сучасна музика», «популярна музика», «попса» тощо. 3 метою максимально точного цитування в нашому дослідженні будуть використовуватись ті терміни, які використовують дослідники, праці яких ми будемо розглядати. Тому, враховуючи необхідність введення в проблему нашого дослідження, пропонуємо оптимізований огляд генезису естрадного мистецтва як передумови розвитку сучасного естрадного вокального виконавства.

Становлення сучасного музичного мистецтва було викликано бурхливими змінами в суспільстві: цивільними та світовими війнами, економічними кризами, впливами східних культур і джазу, науковотехнічним прогресом, урбанізацією тощо. Воно є не простим співіснуванням різних автономних і не залежних один від одного жанрів та стилів мистецтва, а логічним ланцюгом трансформацій класичних традицій, які розпочались ще в епоху романтизму. Воно також характеризується секуляризацією та відмовою від метафізичної віри «в буття Великого Іншого (Бога, Духа, вищої духовної сфери позалюдської свідомості)»², трансформацією, а найчастіше, підміною цінностей.

Після Громадянської війни (1861-1865) та звільнення «чорного» населення Північної Америки від рабства відбувся величезний підйом і розквіт негритянської музики, в надрах якої зародилися специфічні американські національні музичні жанри - спірічуелс, кейкуок, блюз, регтайм, госпел, «джаз-бенд» та інші. Поєднання афро-американської національної музики та західноєвропейських традицій сприяло появі джазу - першого явища американської музики, яке, безперечно, має вплив на світове мистецтво XX - початку XXI століть.

В епоху авангарду «ідея обов'язково максимально прогресивного рівня музичного матеріалу» ${ }^{3}$ ознаменувалась відмовою від будь-яких традиційних елементів музичної мови в серійній техніці, пуантилізмі та алеаториці. Спроби змінити суспільство, які були властиві початку XX століття, стають неактуальними. Т. Адорно зазначив, що після жахів двох світових війн, депресій, світових криз, знищення цілих народів, «до мистецтва долучилося щось абсурдне, божевільне; і якщо мистецтво збурене абсурдом, то це неостаточна спроба приборкати реальний абсурд» ${ }^{4}$. У ньому виразно проглядалися синтезування, інтерпретації й

\footnotetext{
${ }^{2}$ Бычков В. Триалог: Разговор Первый об эстетике, современном искусстве и кризисе культуры / В. Бычков, Н. Маньковская, В. Иванов. Москва : ИФРАН, 2007. С. 9.

3 Папенина А. Зарубежный музыкальный авангард 1950-60-х годов: композиционно-жанровые принципы и проблемы художественного восприятия / А. Папенина. Санкт-Петербург : СПбГУП, 2006. C. 10

4 Адорно Т. Избранное: Социология музыки / Т. Адорно, перев. М. Левина. Москва ; СанктПетербург : Университетская книга, 1998. С. 164 
метаморфози різних форм, що спираються на весь накопичений людством досвід; переосмислювався та оновлювався понятійнокатегоріальний апарат ; здійснювався злам стереотипів, розмивалися усталені жанрові кордони, виникали нові жанри; з'являлися самобутні композиційно-технологічні принципи та системи звукових відносин; розширювався звуковий простір; оновлювалась нотація, інструментарій, прийоми виконання тощо.

Постмодернізм як світоглядно-мистецький напрям став символом постіндустріального суспільства. Ідеї необмеженої свободи, що не принесли поліпшення у світі, в цей період піддалися сильній переоцінці та трансформації, у зв'язку з цим велика кількість авторів повернулась до опори на традиції попередніх епох. Ознаками музичного постмодерну, на думку Н. Щербакової, стали «варіант “звалища як картини світу”, що виникає в полістилістичних опусах; мінімалізм, який поставив на перше місце простоту музичної мови; і тиша, що скріпляє естетичні пошуки віддалених у часі художніх напрямів і різних у своїй основі культур» 6 . У мистецтві відбувалися «процеси руйнування цілісності, єдності художнього феномену, розмивання його меж» ${ }^{7}$. На відміну від авангарду, який повністю відмовлявся від традиції, мистецтво постмодернізму проголошувало прийняття минулого, зверталося до класичних традицій як до джерела натхнення, але відмовлялося «від глибинного осягнення смислів, які несе традиція» ${ }^{8}$. У ньому використовувались класичні естетичні категорії, але зі значними трансформаціями відповідно до сучасних тенденцій. Синтез традицій минулого і сучасності, банального i вишуканого, «низького» (масового) і «високого» (класичного) мистецтв, музичних і позамузичних засобів виразності, що символізує музичне мистецтво, починаючи 3 другої половини XX століття, відбився у полістилістиці (від грец. polus - багато та стиль) як поєднанні в одному творі «різних стилістичних явищ та стилістичній різнорідності, що виникає в результаті застосування ряду технічних прийомів» ${ }^{9}$. Синтез «традиційних» i «нових» композиційних технік, що найбільш яскраво відбився в полістилістиці, ознаменував собою твердження синтетичного типу мислення та універсальної художньої мови. Новий тип музичного мислення викликав необхідність пошуку і створення абсолютно нових засобів і форм художньо-музичного вираження для «нової музики».

\footnotetext{
5 Папенина А. Зарубежный музыкальный авангард 1950-60-х годов: композиционно-жанровые принципы и проблемы художественного восприятия. С. 11.

${ }^{6}$ Щербакова Н. Новый звуковой мир в отечественном музыкальном искусстве второй половины XX века : автореф. дис. ... канд. искусствовед. Саранск, 2009. 17 с.

Сегеда Н. Професійний розвиток викладача музичного мистецтва : історія, методологія, теорія [монографія]. Київ : НПУ ім. М. П. Драгоманова, 2011. С. 18.

8 Данилова А. Своеобразие интерпретации категории «традиция» в эстетической теории и практике постмодернизма (на материале творчества Э. Денисова): дис. ... канд. филос. наук / А. Данилова. Владимир, 2009. С. 62. C. 336 .

Музыкальная энциклопедия / Гл. ред. Ю. Келдыш. Т. 4. Москва : Советская энциклопедия, 1978.
} 
Світова тенденція до комунікаційного діалогу різних культур, стилів, традицій, форм музичної діяльності в сучасну епоху інформатизації світу еволюціонує та «виступає важливим фактором актуалізації проблеми діалогу у зв'язку з необхідністю пошуку нових основ цілісної смислової реалізації людини у світі» ${ }^{10}$. Лейтмотивом початку XXI століття стає ідея не фатальної кризи, яку треба сприймати як новий порядок і навчитись ऑï використовувати ${ }^{11}$. Сучасні гуманістичні «ідеї відкритого суспільства та базової цінності людської свободи» й технічна революція у сфері засобів інформації, вважає П. Куртц, робить людство єдиною планетарною сім'єю i дає можливість «безпосередньо взаємодіяти практично $з$ кожним у будь-якій точці світу, <..> знайти загальний грунт для різних культур, що існують на світовій арені» ${ }^{12}$.

Звернення до позаєвропейських музичних культур, яке можна спостерігати в сучасних естрадних вокальних композиціях, сприяє поверненню до імпровізації, властивій народній музиці, починаючи 3 моменту пї зародження (але практично «зникнувшої» на початку XIX століття), до мікрохроматики, автентичних способів інтонування й артикуляції, поліритмії й поліметрії, які також не були нововведенням, а існували 3 давніх часів у народній музиці різних етносів. Результатом цього стала кардинальна трансформація музики у всьому світі.

Отже, процес відходження від традицій класичної музичної системи, що почався ще в епоху романтизму, дійшовши до свого апогею в авангарді, сприяв появі нової музичної реальності, яка, з одного боку, підбиває підсумки розвитку музики попередніх епох, а 3 іншого - $\epsilon$ точкою відліку нової музики третього тисячоліття.

Осмислення цих процесів дає можливість належним чином розуміти та сприймати такий далекий від західноєвропейської класичної традиції й такий близький та зрозумілий різним верствам населення вид мистецтва, як сучасна естрадна музика.

Масовій музичній культурі, частиною якої $є$ естрадне мистецтво, вважає А. Васюрина, притаманна оригінальна, специфічна семантична система, свій вокальний та інструментальний виконавський стиль, який має єдину основу, що виявляється в особливих, самостійно визначених формах музичного буття, пов'язаних $з$ повсякденно-практичним життям людини, та свою характерну музичну мову ${ }^{13}$.

Л. Сбітнєва вважає, що загальна для XX століття тенденція до інтернаціоналізації музичного мистецтва доведена «на естраді до

\footnotetext{
${ }^{10}$ Самойленко О Діалог як музично-культурологічний феномен: методологічні аспекти сучасного музикознавства: автореф. д. мистецтвознавства / О. Самойленко. К.; 2003. С. 6.

${ }^{11}$ Сегеда Н. Професійний розвиток викладача музичного мистецтва: історія, методологія, теорія. C. 19 .

${ }^{12}$ Куртц П. Гуманизм и скептицизм - парадигмы культуры третьего тысячелетия // Здравый смысл, 2000, 17.

13 Васюрина А. Социально-эстетический анализ массовой музыкальной культуры : автореф. дис. ... канд. филос. наук. Київ,1996.
} 
абсолюту» ${ }^{14}$ та проявляється у використанні універсальних мелодичних і ритмічних конструкцій та прийомів аранжування, електронних та народних інструментів, запозичених з різноманітних народних мелодій та манер виконання.

Жанровий різновид популярної музики, у якому в підкреслено чуттєвій манері об'єдналися комерційний джаз, фольклорний початок, поетичне слово, танцювальні рухи тощо, сформувався на комерційній естраді на початку XX століття в Америці, а потім захопив і весь світ. Відповідно до цього значно змінилася і вокальна музика легкого жанру, яка стала являти собою симбіоз міської пісні та національного фольклору, які нашаровуються на традиції американської комерційної музики та джазу. Ї̈̈ основою став «розмовний просторічний стиль» ${ }^{15}$ співу, який спряв виникненню i розвитку багатьох нових жанрів світської музики упродовж всього XX та початку XXI століть. 3 появою рок-музики популярна музика доповнилась новими рисами, такими як модальність древніх селянських ладів, що лежать в основі мелодійної структури пісень; носова манера співу; різка акцентованість ритму; важкі, перебільшено підкреслені, регулярні наголоси, притаманні ритменд-блюзу; особлива соматична виразність метроритму, що закликає до співучасті та співтворчості (притупування, прихлопування) тощо ${ }^{16}$ та більша агресивність у поданні звуку.

«Естрадна музика» в американській науці має назву contemporary commercial music (CCM), у перекладі на українську - сучасна комерційна музика (СКМ). Абревіатура СКМ у нашому дослідженні буде використовуватись для позначення сучасної некласичної музики. Цей термін було запропоновано Ж. ЛоВетрі у 2000 році. Автор наголошує на тому, що він не має жодної асоціації з комерцією, а використовується як загальний термін, який охоплює всі жанри некласичної популярної музики ${ }^{17}$, такі як музичний театр, кабаре, кантрі, госпел, джаз, соул, рок, $\mathrm{R} \& \mathrm{~B}$ тощо ${ }^{18}$.

В українському мистецтвознавстві цей вид мистецтва об'єднує всі різновиди музичних жанрів, які легко сприймаються ${ }^{19}$. Нові вокальні техніки, які відповідають СКМ, у світовій музичній спільноті мають

\footnotetext{
${ }^{14}$ Сбітнєва Л. Розвиток системи музично-естетичного виховання дітей і молоді в Україні (друга половина XX століття) : дис. ... д. пед. наук. Київ, 2016. С. 189.

${ }^{15}$ Winnie B. Contemporary vocal technique in the choral rehearsal: Exploratory strategies for learning: Doctoral Theses. University of Washington, 2014. C. 30.

${ }_{16}$ Конен В. Третий пласт: Новые массовые жанры в музыке ХХ века: монография. Москва : Музыка, 1994. С. 151-152.

${ }^{17}$ LoVetri, J. Why We Are Here Today / J. LoVetri. Introductory remarks at Olivet Nazarene University CCM Seminar, November 16-17, 2007. Наведено за: Woodruff N. Contemporary Commercial Voice Pedagogy Applied to the Choral Ensemble: An Interview with Jeannette LoVetri. Choral Journal, 2011, 52, (5). P. 39-53.

${ }_{18}$ LoVetri, J. Contemporary commercial music / J. LoVetri. Journal of Voice, 2008. 22(3). p. 260-262.

${ }_{19}$ Откидач В. Естрадний спів і шоу-бізнес: навч.-метод. посіб. / В. Откидач. Вінниця : Нова Книга, 2013. c. 12.
} 
назву contemporary vocal techniques (CVT), в перекладі на українську сучасні вокальні техніки (СВТ).

Згідно з К. Кішімото та Т. Снайдер «популярна музика» - це великий і широко визначений корпус музики в популярній ідіомі XX та XXI століть, яка зазвичай виконується й записується для масового споживання та не підпадає під закони західної класичної музики ${ }^{20}$. Вона, як і фольклор, вважають К. Ван Malssen ${ }^{21}$, К. Кішімото й Т. Снайдер ${ }^{22}$, О. Шумахер ${ }^{23}$ та інші, по суті є усною звуковою традицією, на відміну від класичної, в якій класичні виконавці «повинні дотримуватись певних занотованих інструкцій, пов'язаних з тим періодом, в якому створено твір» ${ }^{24}$, а «індивідуальність виконавця <... відбивається через інтерпретацію та засоби виразності» ${ }^{25}$.

В. Боумен розглядає популярну музику як ту, що «створена особливо для того, щоб нею насолоджуватися і збагатити повсякденних людей в повсякденному житті» ${ }^{26}$ і виокремлює іiі характерні риси, такі як: широта передбачуваного звернення; масове посередництво та товарний характер; аматорські взаємодії; невіддільність від повсякденних турбот; неформальність; тут-і-зараз прагматичне використання та корисність; звернення до втіленого досвіду; акцент на процесі ${ }^{27}$.

Т. Самая виокремлює сім базових принципів естрадного мистецтва, до яких вона відносить: відкритість, яка базується на активному діалозі артиста з публікою, коли виконавець сприймає іï як партнера; легкість, яку автор окреслює як специфіку сприйняття естрадного твору, за якої немає потреби в попередній підготовці слухача; синтетичність, яка зумовлює поєднання в естрадному номері елементів різних видів (театрального, музичного, хореографічного та циркового тощо); лаконізм, який передбачає високу концентрацію змісту, стислість, автономність та завершеність художнього образу; імпровізаційність як відкритість до реакції аудиторії, вміння вирішувати складні сценічні ситуації, коригувати манеру подачі та способи спілкування з публікою, зміщувати акценти у номері з урахуванням iï симпатій; мобільність, яка поділяється на професійну (здатність артиста до виконання сценічної

\footnotetext{
${ }^{20}$ Kishimoto K., Snyder T.. 2016. Popular Music in FRBR and RDA: Toward User-Friendly and Cataloger-Friendly Identification of Works. Cataloging \& Classification Quarterly, 2016, 54(1): p. 60-86.

21 Van Malssen, Kara. 2014. BIBFRAME AV Modeling Study: Defining a Flexible Model for Description of Audiovisual Resources. Appendix A: Recorded Sound Issues Related to Music Types. $4 \mathrm{c}$.

${ }^{22}$ Kishimoto K., Snyder T.. 2016. Popular Music in FRBR and RDA: Toward User-Friendly and Cataloger-Friendly Identification of Works.

23 Schumacker A. Incorporating Popular Music Into The Choral Classroom: Doctoral Theses / A. Schumacker. Coral Gables, Florida, 2013. p. 15.

24 Van Malssen, Kara. 2014. BIBFRAME AV Modeling Study: Defining a Flexible Model for Description of Audiovisual Resources. C. 1.

${ }^{25}$ Van Malssen, Kara. 2014. BIBFRAME AV Modeling Study: Defining a Flexible Model for Description of Audiovisual Resources. C. 2.

${ }_{26}^{6}$ Bowman W. Pop' Goes...? Taking Popular Music Seriously. Bridging the gap : popular music and music education / ed. by Carlos Xavier Rodriguez. Reston : MENC, 2004. C. 36.

${ }^{27}$ Bowman W. Pop' Goes...? Taking Popular Music Seriously. C. 36-37.
} 
діяльності за будь-яких умов) та соиіальну (здатність до оперативного реагування на запити суспільства); індивідуальність, яка виявляється у постійному пошуку оригінальності, самобутності, індивідуальної виконавської манери, власного сценічного образу ${ }^{28}$.

Аналізуючи етнокультурні виміри поп-культури в Україні, В. Плахотнюк визначає «особливості засвоєння фольклорних традицій в іншокультурних реаліях та афро-американський вплив на формування естрадного репертуару» ${ }^{29}$, що визначає поп-музику «як метахудожній, метакультурний синтез мистецтв» ${ }^{30}$. Наявність іншокультурних музичних впливів на український національний грунт вітчизняної популярної музики також підкреслює О. Бойко ${ }^{31}$.

У сучасній українській естрадній музиці, вважає В. Тормахова, спостерігаються дві головні тенденції, а саме: наслідування західних традицій та створювання власних музичних напрямів на фольклорній основі. Вона виокремила іiі основні риси, а саме: орієнтація на стандарти хіта; тяжіння до стильового синтезу та утворення нових стильових напрямів на основі об'єднання старих; ритмічний супровід ударних; чітка симетрична форма; широке використання електронних інструментів i сучасних комп'ютерних програм 3 обробки звуку; використання архаїчного вітчизняного фольклору як основи для створення естрадних композицій (а також звернення до автентичної вокальної манери виконання, використання народних інструментів, їх тембрів та особливостей гри на них); звернення до фольклору народів світу ${ }^{32}$. Автор підкреслює, що фольклор $є$ схожим 3 джазом, рок- і поп-музикою за основними загальними ознаками, а саме: колективність, анонімність й імпровізаційність творчості, варіативність трактувань одного й того ж твору, та, що $\epsilon$ фундаментальним, відсутність чіткої межі між виконавцями й аудиторію, яка виявляється у спрямованості на слухача та його сприйняття; залученні слухача до участі в «єдиному креативному акті»; наявності особливих костюмів, танців, жестів, символіки тощо.

Провідну тенденцію розвитку естради в незалежній Україні окреслив М. Мозговий ${ }^{33}$ і сформулював $\dddot{1 і ̈ ~ я к ~ п р а г н е н н я ~ м у з и к а н т і в-е с т р а д н и к і в ~}$ якомога тісніше інтегруватися у світовий ринок шоу-бізнесу і стрімку адаптацію до ринкових відносин.

\footnotetext{
${ }^{28}$ Самая Т. Вокальне мистецтво естради як чинник культурного життя України другої половини XX - початку XXI століття : дис. ... канд. мистецтвозн.. Київ, 2017. 199 с.

29 Плахотнюк В. Етнокультурні виміри поп-культури у становленні виконавських естрадних колективів. Міжнародний науковий журнал «Науковий огляд», 2014, 6 (5).

30 Плахотнюк В. Естрадний синтез мистецтв. Культура і мистецтво у сучасному світі, $2010,11$. C. 259 .

31 Бойко О. Українська масова музика: етапи розвитку, національні особливості : дис. ... канд. мистецтвозн. Київ, 2017. С. 176.

32 Тормахова В. Українська естрадна музика і фольклор: взаємопроникнення і синтез : автореф. дис. .... канд. мистецтвозн. Київ, 2007.

${ }_{33}$ Мозговий М. Становлення і тенденції розвитку української естрадної пісні : автореф. дис... канд. мистецтвозн. Київ, 2007. С. 13.
} 
Отже, сучасна естрадна музика являє собою синтетичний жанр, у якому переплітаються різнорідні елементи різних культур, а їх джерелами $\epsilon$ фольклор, до того ж у кожному етносі він має свої, притаманні саме йому (етносу) риси. Але слід враховувати те, що американська некласична музика 3 появою джазу, витоками якого теж є фольклор, більш ніж будь-яка музична культура світу вплинула на світову музику легких жанрів і не лише суто у питаннях урізноманітнення вокальних жанрів, але й в актуалізації в мистецькій галузі економічного аспекту як певного критерію відповіді на попит щодо музики різної якості.

\section{2. Характерні риси сучасного естрадного вокального виконавства}

Нова мистецька парадигма позначила твердження синтетичного типу мислення, а однією з головних особливостей мистецтва, зокрема попмузики, стала заміна поняття «стиль епохи» на протилежне - «епоха стилів», що природно призвело до появи нової універсальної музичної мови, в якій чітко простежується тенденція повернення до «старих» природних можливостей людського організму і відповідних ним способів i прийомів звуковидобування. Як історично-відповідна категорія «музична мова легких жанрів», констатує В. Конен, тяжіє найчастіше або до міського фольклору, або до інтонацій і формотворчих прийомів професійної музики минулого, заснованих на простих, співучих, мелодіях i танцювальних ритмах, які легко запам'ятовуються ${ }^{34}$. Естрадний спів, вважають Є. Дуков та I. Богданов, «займає проміжну нішу між академічним і народним (співом), не змішуючись ні 3 тим, ні з іншим» ${ }^{35}$. Його особливістю $є$ «пошук свого власного звуку, своєї характерної, легко впізнаваної манери співу», на відміну від академічного і народного, які «освоюють сформований канон»; необхідність легко і невимушено рухатися, наявність важких для виспівування фраз, що вимагають швидкої зміни дихання, «вміння досягти “драйву”, опанувати фальцет, виконувати йодль, субтон і безліч інших варіантів і комбінацій вокальної техніки, необхідних для інтерпретації сучасних пісень ${ }^{36}$. Л. Сбітнєва висловила думку про те, що український естрадний спів характеризується «плавними мелодіями, відсутністю великих інтервалів, середньою теситурою, чітким промовлянням слів, чистотою інтонацій, стриманою динамікою i загальним благородством стилю» ${ }^{37}$, які притаманні українській народній співочій традиції.

Виникнення нових жанрів і використання електронних інструментів та мікрофону актуалізували нові вокальні якості, які дозволяють

\footnotetext{
${ }^{34}$ Конен В. Этюды о зарубежной музыке. Изд. 2-е, доп. Москва : Музыка, 1975. С. 460.

35 Дуков Е., Богданов И. Эстрадное образование в России. Эстрада сегодня и вчера. О некоторых эстрадных жанрах XX-XXI веков. Сб. ст. Вып. 1/ Гл. Ред. О. Кузнецова. Москва : ГИИ ; 2010. С. 235.

${ }_{37}$ Дуков Е., Богданов И. Эстрадное образование в России. С. 236.

37 Сбітнєва Л. Розвиток системи музично-естетичного виховання дітей і молоді в Україні (друга половина XX століття). С. 188.
} 
використовувати стиль співу не тільки орієнтований на вокальну проєкцію, пов’язану з західною класичною традицією та белтом, а вокальну техніку, яка дає більш інтимні та розмовні вокальні кольори ${ }^{38}$.

Члени Американської академії вокальних педагогів (American Academy of Teachers of Singing - AATS) окреслили типові стилістичні особливості СВТ, а саме: домінування грудного регістру; надзвичайно яскравий тембр; помірне вібрато або взагалі його відсутність; відокремлені, а не згладжені вокальні регістри; розрахування на електронне посилення; навмисне індукування шумового, придихального та назального звучання; опора на розмовну артикуляцію ${ }^{39}$. На відміну від класичної традиції, заснованої на італійському bel canto 3 його ідеально чистим «стерильним» вокальним звуком, розмовні інтонації в сучасній вокальній музиці стали такими ж рівноцінними складниками музичної тканини, як мелодика і звуковисотність. Поява в 70-ті роки XX століття стилю «соул» (soul), який відобразив «секуляризацію євангельської музики», додала до вокальної техніки нові способи звуковедення, такі як нетемпероване інтонування (vocal slurs), рикання (growl), фальцет (falsetto) тощо ${ }^{40}$.

Різні аспекти співвідношення вокального виконавства у всіх стилях СВТ 3 ключовими компонентами класичного вокального виконавства досліджують Т. Бон, М. Гарнієр та Д. Кенні ${ }^{41}$, Г. Холлі ${ }^{42}$, Д. СотоМореттіні $^{43}$, К. Чандлер ${ }^{44}$, Р. Едвін ${ }^{45}$, А. Едіссон зі співавторами ${ }^{46}$, Дж. Естилл ${ }^{47}$ тощо. Спираючись на дефініції цих досліджень, ми виокремили загальні відмінності СВТ від техніки bel canto, a саме: розширення меж акустичних характеристик (акустична енергія, обертони, формантні зони, положення піднебіння, якість звуку, вібрато); більш чітко визначена природність фізіологічних процесів (дихання, вид голосоведення, атака, домінуючий голосовий механізм, співочий тон, діапазон, регістраційні переходи), які супроводжують некласичний спів; інтуїтивність, неофіційність та неформальність виконавських дій (вимова тексту, візуалізація, місце виконання, багатоголосся, теоретичні

\footnotetext{
${ }^{38}$ Lebon R. The Versatile Vocalist: Singing Authentically in Contrasting Styles and Idioms / R. Lebon. Lanham, MD: Scarecrow Press. 2006.

${ }^{39}$ Addison A. \& Others. In Support Of Contemporary Commercial Music (Nonclassical) Voice Pedagogy / A. Addison, E. Bonazzi, L. Christiansen, P. Craig \& Others. Journal of Singing, 2008, 65(1), c. 8-9.

${ }^{40}$ Lebon R. The Versatile Vocalist: Singing Authentically in Contrasting Styles and Idioms.

41 Bourne T. Garnier M., Kenny D. Music Theater Voice: Production, Physiology and Pedagogy / T. Bourne, M. Garnier, D. Kenny. Journal of Singing, 2011, 67(4), p. 437-444.

${ }^{42}$ Holley G. From Classical to Music Theatre: A Vocalist's Experience: Doctoral Theses. South Brisbane, 2016. p. 35.

${ }^{43}$ Soto-Morettini D. Popular Singing: A Practical Guide to Pop, Jazz, Blues, Rock, Country and Gospel / D. Soto-Morettini. London : A \& C Black, 2006. 192 p.

${ }^{44}$ Chandler K. Teaching Popular Music Styles. Teaching Singing in the 21st Century, 2014, pp. 35-51.

${ }_{45}$ Edwin R. From Classical to Pop: A Case Study. Journal of Singing, 56:3 January, 2000, p. 71-72.

46 Addison A. \& Others. In Support Of Contemporary Commercial Music (Nonclassical) Voice Pedagogy. pp. 7-10.

${ }^{47}$ Estill J. Belting and Classical Voice Quality: Some Physiological Differences. Medical Problems of Performing Artists, 1988, 3, pp. 37-43.
} 
знання); опора на загальнолюдські та етнічні традиції (інтонування, рухливість, імпровізація, вокальні ефекти); протилежність КBT (постава, повітряний тиск, положення гортані, вокальне виробництво, положення язику, домінантні м'язи, дикція, вимова звуків, ритм, звукова проєкція, посилення); індивідуальний творчий підхід до співу (візуалізація, вокальні ефекти, тлумачення тексту) тощо.

Ж. ЛоВетрі в інтерв'ю Н. Вудруфф окреслює такі особливості голосової функції в СВТ: відокремлення, трансформація та комбінування грудного та головного регістрів; зміна голосового виробництва та якості голосу для кожного стилю; неспотворені голосні; чітка вимова ${ }^{48}$.

К. Дженнінгс відмічає, що співаки музичного театру, які є одними 3 представників сучасного некласичного вокального мистецтва, віддають перевагу більш яскравому, мовленнєвому підходу до резонансу, використовують більш переднє, але не носове розміщення голосних, горизонтальну форму рота та природну форму глотки. Також автор підкреслює, що тип резонансу визначається смислом тексту або стилем музичної композиції, а значна частина теситури сучасних пісень знаходиться у середньому діапазоні, що дає можливість для чіткої вимови тексту ${ }^{49}$.

Спираючись на вищевикладене та свій актуальний досвід, ми робимо висновок, що естрадний спів $\epsilon$ специфічним видом вокального мистецтва, який органічно поєднує в собі традиційні елементи академічної постановки голосу та специфічну вокальну техніку.

Аналіз виступів фіналу національного відбору Свробачення 2020 показує, що до наведених рис останнім часом додається все більше i більше елементів з музичної мови інших етносів, які часто кардинально відрізняються від української за своєю культурною традицією. Наприклад, східні інтонації в пісні "Call For Love" у виконанні Хайата, або африканські ритми в композиції «Соловей» гурту "Go-A" тощо. Але їх застосування, на нашу думку, не завжди демонструє відповідну якість, адже вітчизняна школа естрадного вокалу, маючи певні успішні результати, не спирається на систематизовану теорію i методику сучасного естрадного вокального виконавства як науку, що має базуватись на культуровідповідній сучасній музикології, зокрема в означеній проблематиці.

Враховуючи розглянуті особливості естрадного виконавства закордонних представників мистецтвознавчої думки та представлені вище його дефініції, пропонуємо візуалізацію складників традиційної класичної вокальної техніки та СВТ (рис. 1).

\footnotetext{
${ }^{48}$ Woodruff N. Contemporary Commercial Voice Pedagogy Applied to the Choral Ensemble: An Interview with Jeannette LoVetri. Choral Journal, 2011, 52, (5). P. 39-53.

49 Jennings C. Belting is beautiful: welcoming the musical theater singer into the classical voice studio: Doctoral Theses. University of Iowa, 2014. C. 31. 


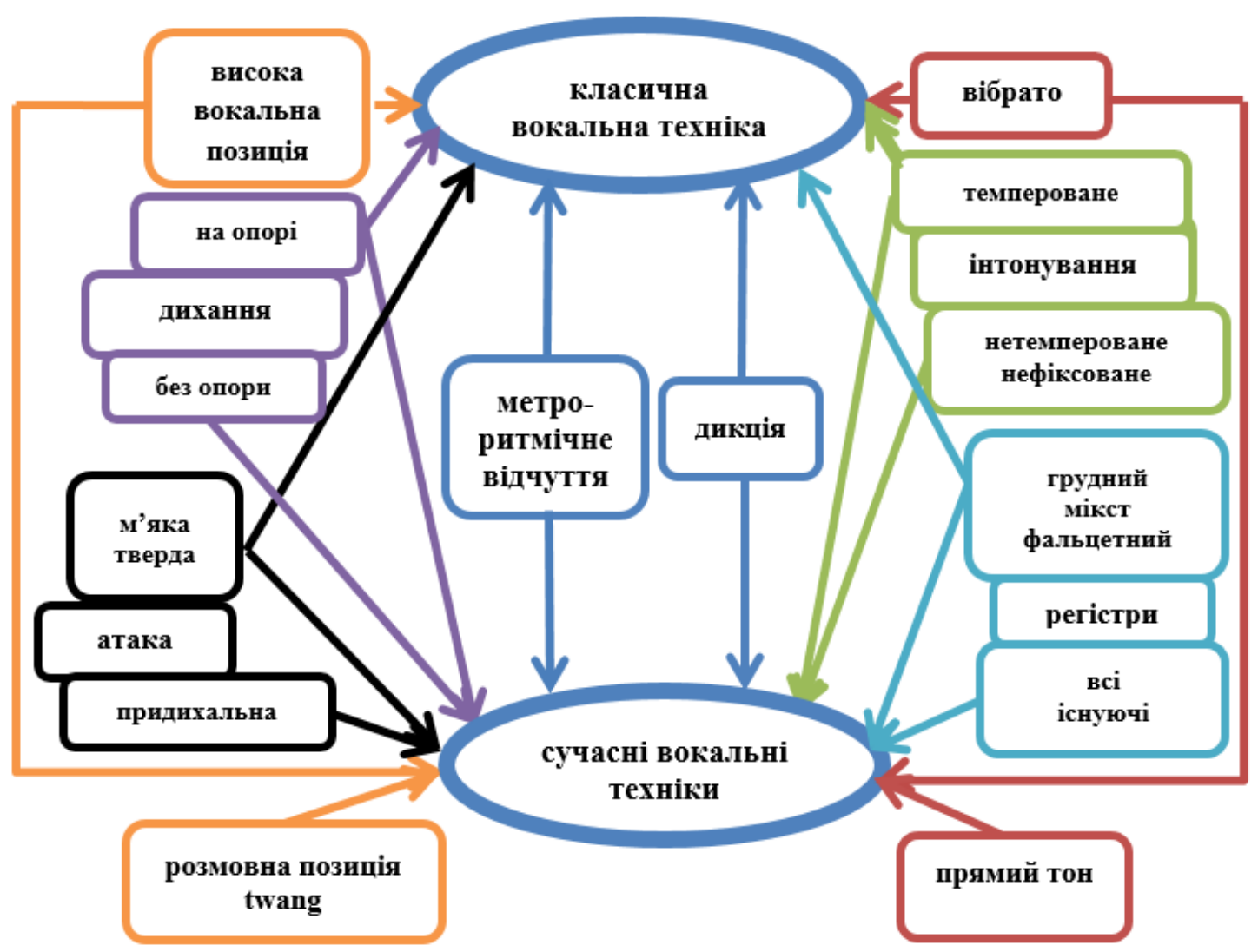

Рис. 1. Складники класичної вокальної техніки та СВТ

3 рисунку видно, що єдиними для СВТ та КВТ є наявність чіткої дикції та метро-ритмічного відчуття, хоча в сучасній естрадній $\mathrm{i}$ особливо джазовій музиці метро-ритм набагато складніший, ніж у традиційній академічній музиці, й потребує особливої уваги та додаткових зусиль до його опанування. Але його основою $є$ загальна для усіх жанрів та стилів музики метрична пульсація. У сучасному вокалі широко використовуються інші елементи традиційної академічної вокальної техніки, а саме дихання на опорі, висока вокальна позиція, темпероване інтонування, використання м'якої й твердої атаки звуку, грудного, мікстового та головного регістрів, вібрато. Водночас в естрадному вокальному виконавстві використовуються і неприпустимі 3 погляду академічної традиції елементи.

Специфічними компонентами естрадного вокального виконавства $\epsilon$ особлива співоча позиція «обличчя в посмішці»; відсутність єдиного способу звукоутворення, звуковидобування i звуковедення, навіть у рамках одного стилю; використання безопорного дихання; застосування під час співу всіх видів атаки (м'яка, тверда, придихальна); природне мовне розташування гортані, збереження мовного забарвлення голосу та мовні інтонації як один з основних виразних засобів; використання будь- 
якого 3 наявних у вокаліста регістрів (штробас (vocal fry), грудний, фальцет, мікст, свистковий) та їх поєднань (гра регістрами); вокальні та позавокальні, розмовні та екстремальні прийоми звуковидобування; специфічні прийоми звуковедення; прямий тон; різні види інтонування; особлива метро-ритмічна організація; вільне ритмічне, мелодичне, стилістичне, темброве тощо трактування основної теми; особливі принципи формоутворення; індивідуальний характер сценічного виступу співака; більш експресивна, розкута манера співу; широке використання автентичних етнічних форм співу, елементів східної музики, афроамериканської культури, блюзу та джазу; синтез різних музичних стилів і напрямів.

До специифічних прийомів звуковидобування належать опертий та неопертий фальцет, спів 3 придихом (subtone), ротовий або носовий призвук (oral/nasal twang), інтонації стогону (wail), інтонації плачу (cry/sob), наспівування (crooning), компресований звук, вокальний крик (belt), вигуки (shout) тощо; до екстремальних - рикання (growl), не вокальний крик (scream), скрип (creak), дрязкання (rattle), спотворений звук (distortion, rasp).

Специфічні прийоми звуковедення сучасного некласичного вокального виконавства складають глибока діафрагмальна вібрація, специфічні форшлаги, так звані підтяжки (bending), плавний «глісандуючий» перехід 3 ноти на ноту (slide); інструментальне глісандо (smear); розспівний орнаментальний пасаж на основі пентатоніки (running) тощо.

Інтонаційному строю естрадної музики притаманні види інтонування, які були взяті з джазу, а саме: нетемпероване інтонування (dirty tone), нефіксоване інтонування (off pitch tone), блюзові тони (blue tones), невипадкові мікровідхилення висоти звуку, блюзова альтерація (знижені нижче відповідних європейських альтерованих звуків терція і септима, яке також не є фіксованими тонами) та, як наслідок, відсутність ввідного тону (в завершальних кадансах до тоніки переходять від «блюзової терції», від секунди або від нижньої сексти) тощо. 3 джазу взятий також «індивідуальний» тембр, який може інтерпретуватись залежно від завдань художнього, творчо-виразового мислення та багатогранних можливостей музиканта-виконавця.

Виконавські інтерпретації естрадних пісень часто містять «багато оригінального музичного матеріалу, включаючи змінені мелодії чи акорди, змінений текст та додані інструменти, а іноді виконуються у зовсім іншому, від того, який спочатку передбачав автор пісень, стилі чи жанрі ${ }^{50}$. Виконавці використовують значні музичні цитування, такі як семпли, пародія, ремікс, машап та запозичення мелодії чи тексту ${ }^{51}$.

\footnotetext{
${ }^{50}$ Kishimoto K., Snyder T. Popular Music in FRBR and RDA: Toward User-Friendly and CatalogerFriendly Identification of Works.

${ }^{51}$ Kishimoto K., Snyder T. Popular Music in FRBR and RDA: Toward User-Friendly and CatalogerFriendly Identification of Works.
} 
Ще у 1975 році А. Сохор у своїй монографії відзначав, що «основою комунікабельності індивідуальної творчості $\epsilon$ перевершення хоча б деяких загальноприйнятих і загальнопомітних інтонаційних типів, у тому числі (хоча і не тільки!) народжених у народній пісні й в міській побутовій музиці - цих потужних джерел інтонаційного словника епох, що $є$ підгрунтям концертних та театральних жанрів». Виконавець, на його думку, є «учасником створення музичних цінностей, в певному роді їх співавтором», особиста інтерпретація якого визначається не тільки попередньо сформульованим задумом, але i безпосереднім впливом публіки в момент виконання ${ }^{52}$. Одним 3 основних показників індивідуальності виконавця є «саунд (просторово-звуковий образ) інтегральна характеристика звучання голосу вокаліста, його індивідуальна тембрація» ${ }^{53}$. Індивідуальність ми вважаємо найважливішою рисою естрадного мистецтва через те, що якими б технічними навичками не володів артист, якщо його інтерпретація твору, який може бути досить примітивним, не виділяється з загальної маси виконавців, не демонструє самовираження засобами музичного мистецтва, - завоювати любов публіки йому буде дуже важко.

\section{ВИСНОВКИ}

Враховуючи вищезазначене та свій актуальний досвід, ми наголошуємо, що сучасне естрадне вокальне виконавство - це рівноправний, специфічний вид вокального мистецтва XXI століття, в якому: органічно взаємодіють інтонації народних пісень і міської побутової музики кожного окремого етносу та традиційна і специфічна вокальні техніки; відбувається синергія всіх наявних жанрів і стилів музики (в тому числі джазу, блюзу, соулу, R\&B), навіть у межах одного твору; не має єдиного еталону виконання; знаходиться в постійному пошуку нових засобів виразності.

Тому особливості сучасного естрадного вокального виконавства необхідно враховувати під час роботи з естрадними вокалістами в закладах всіх типів і рівнів освіти, під час розробки методики навчання естрадному співу та укладанні освітніх програм, під час оцінювання якості публічних виступів естрадних співаків з урахуванням основних особливостей виконання позаєвропейської вокальної музики, музики для театру тощо, а соціальна роль музиканта змінюється - 3 виконавця на співавтора мистецького твору.

Ця проблематика потребує подальшого аналізу й обговорення та продовження наукових досліджень у сфері сучасної музикології, зокрема питань теорії естрадного мистецтва і виконавства та естрадної вокальної педагогіки.

\footnotetext{
${ }_{53}$ Сохор А. Социология и музыкальная культура. Москва : Советский композитор, 1975. 208 с.

53 Самая Т. Вокальне мистецтво естради як чинник культурного життя України другої половини XX - початку XXI століття. С. 5.
} 


\section{ЛІТЕРАТУРА}

1. Addison A., Bonazzi E., Christiansen L., Craig P. \& Others. In Support Of Contemporary Commercial Music (Nonclassical) Voice Pedagogy / A. Addison, E. Bonazzi, L. Christiansen, P. Craig \& Others. Journal of Singing, 2008, 65(1), pp. 7-10.

2. Адорно Т. Избранное: Социология музыки. Перев. М. Левина. Москва ; Санкт-Петербург : Университетская книга, 1998. 445 с. ISBN 5-7914-0041-1 ISBN 5-7914-0023-3.

3. Бойко О. Українська масова музика: етапи розвитку, національні особливості : дис. ... канд. мистецтвозн. Київ, 2017. 215 с.

4. Bowman W. Pop' Goes...? Taking Popular Music Seriously. Bridging the gap : popular music and music education / ed. by Carlos Xavier Rodriguez. Reston : MENC, 2004. 247 p. ISBN-1-5654-5158-9.

5. Bourne T. Garnier M., Kenny D. Music Theater Voice: Production, Physiology and Pedagogy. Journal of Singing, 2011, 67(4), p. 437-444.

6. Бычков В. Триалог: Разговор Первый об эстетике, современном искусстве и кризисе культуры / В. Бычков, Н. Маньковская, В. Иванов. Москва : ИФРАН, 2007. 239 с. ISBN 978-5-9540-0087-0.

7. Van Malssen Kara. 2014. BIBFRAME AV Modeling Study: Defining a Flexible Model for Description of Audiovisual Resources. Appendix A: Recorded Sound Issues Related to Music Types. URL http://www.loc.gov/ bibframe/docs/pdf/av-appendix-a.pdf.

8. Васюрина А. Социально-эстетический анализ массовой музыкальной культуры : автореф. дис. ... канд. филос. наук. Киев, 1996.

9. Winnie B. Contemporary vocal technique in the choral rehearsal: Exploratory strategies for learning: Doctoral Theses / B. Winnie. University of Washington, 2014. $135 \mathrm{p}$.

10. Woodruff N. Contemporary Commercial Voice Pedagogy Applied to the Choral Ensemble: An Interview with Jeannette LoVetri. Choral Journal, 2011, 52, (5). P. 39-53.

11. Данилова А. Своеобразие интерпретации категории «традиция» в эстетической теории и практике постмодернизма (на материале творчества Э. Денисова) : дис. ... канд. филос. наук. Владимир, 2009. 156 с.

12. Jennings $C$. Belting is beautiful: welcoming the musical theater singer into the classical voice studio: Doctoral Theses / C. Jennings. University of Iowa, 2014. $98 \mathrm{p}$.

13. Дуков Е., Богданов И. Эстрадное образование в России. Эстрада сегодня и вчера. О некоторых эстрадных жанрах XX-XXI веков. Сб. ст. Вып. 1 / Гл. Ред. О. Кузнецова. Москва : ГИИ; 2010. С. 188-239. ISBN: 978-5-98287-021-6

14. Kishimoto K., Snyder T.. 2016. Popular Music in FRBR and RDA: Toward User-Friendly and Cataloger-Friendly Identification of Works. I 
K. Kishimoto, T. Snyder. Cataloging \& Classification Quarterly, 2016, 54(1): p. 60-86. DOI https://doi.org/10.1080/01639374.2015.1105898.

15. Конен В. Третий пласт: Новые массовые жанры в музыке XX века: монография. Москва : Музыка, 1994. 160 с. ISBN 5-71404)407-8.

16. Конен В. Этюды о зарубежной музыке. Изд. 2-е, доп. / Валентина Конен. Москва : Музыка, 1975. 480 с.

17. Куртц П. Гуманизм и скептицизм - парадигмы культуры третьего тысячелетия. Здравый смысл, 2000, 17. URL: http:/humanism.al.ru/ru/.

18. Lebon R. The Versatile Vocalist: Singing Authentically in Contrasting Styles and Idioms / R. Lebon. Lanham, MD: Scarecrow Press. 2006. ISBN13: 978-0810853515, ISBN-10: 0810853515.

19. Левинас Э. Философское определение идеи культуры. Глобальные проблемы и общечеловеческие ценности: Пер.с англ. и франц. / Сост. Л. Василенко, В. Ермолаев; Вводн.ст. Ю. Шрейдера. Москва : Прогресс, 1990. 495 c. ISBN 978-5-94865-208-5.

20. LoVetri J. Why We Are Here Today. Introductory remarks at Olivet Nazarene University CCM Seminar, November 16-17, 2007. Наведено за: Woodruff N. Contemporary Commercial Voice Pedagogy Applied to the Choral Ensemble: An Interview with Jeannette LoVetri. Choral Journal, 2011, 52, (5). P. 39-53.

21. LoVetri J. Contemporary commercial music. Journal of Voice, 2008, 22(3). p. 260-262. DOI: https://doi.org/10.1016/j.jvoice.2006.11.002.

22. Мозговий М. Становлення i тенденції розвитку української естрадної пісні : автореф. дис... канд. мистецтвозн. Київ, 2007. 175 с.

23. Музыкальная энциклопедия. / Гл. ред. Ю. Келдыш. Т. 4. Москва : Советская энциклопедия, $1978.976 \mathrm{c.}$

24. Откидач В. Естрадний спів і шоу-бізнес : навч.-метод. посіб. / В. Откидач. Вінниця : Нова Книга, 2013. 368 с. ISBN 978-966-382-423-9.

25. Папенина А. Зарубежный музыкальный авангард 1950-60-х годов: композиционно-жанровые принципы и проблемы художественного восприятия : автореф. диссерт. ... канд. искусствовед. Санкт-Петербург : СПбГУП, 2006. 18 с.

26. Плахотнюк В. Естрадний синтез мистецтв. Культура і мистещтво у сучасному світі. 2010, 11. C. 259-266. URL http://nbuv.gov.ua/UJRN/ Kmss_2010_11_36.

27. Плахотнюк В. Етнокультурні виміри поп-культури у становленні виконавських естрадних колективів. Міжнародний науковий журнал «Науковий огляд». 2014, 6(5). URL: http://www.sciary.com/journalscientific-scirewarticle-255852.

28. Самая Т. Вокальне мистецтво естради як чинник культурного життя України другої половини XX - початку XXI століття : дис. ... канд. мистецтвозн. Київ, 2017. 199 с. 
29. Самойленко О Діалог як музично-культурологічний феномен: методологічні аспекти сучасного музикознавства : автореф. ... д. мистецтвознавства. Київ, 2003. 50 с.

30. Сбітнєва Л. Розвиток системи музично-естетичного виховання дітей і молоді в Україні (друга половина XX століття) : дис. ... д. пед. наук. Київ, 2016. 402 с.

31. Сегеда Н. Професійний розвиток викладача музичного мистецтва: історія, методологія, теорія : монографія. Київ : НПУ ім. М. П. Драгоманова, 2011. $273 \mathrm{c}$.

32. Soto-Morettini D. Popular Singing: A Practical Guide to Pop, Jazz, Blues, Rock, Country and Gospel. London : A \& C Black, 2006. DOI https://doi.org/10.1080/23268263.2007.10769797.

33. Сохор А. Социология и музыкальная культура. Москва : Советский композитор, 1975г. 208 с. ISBN: 100-0-00001-950-9.

34. Тормахова В. Українська естрадна музика i фольклор: взаємопроникнення і синтез : автореф. дис. ... канд. мистецтвозн. / В. Тормахова. Київ, 2007. 21 с.

35. Holley G. From Classical to Music Theatre: A Vocalist's Experience: Doctoral Theses. South Brisbane, 2016. 110 p.

36. Chandler K. Teaching Popular Music Styles. Teaching Singing in the 21st Century, 2014, pp. 35-51. DOI: 10.1007/978-94-017-8851-9_4.

37. Schumacker A. Incorporating Popular Music Into The Choral Classroom: Doctoral Theses. Coral Gables, Florida, 2013. 168 p.

38. Щербакова Н. Новый звуковой мир в отечественном музыкальном искусстве второй половины XX века : автореф. дис. ... канд. искусствовед. Саранск, 2009. 17 с.

39. Edwin R. From Classical to Pop: A Case Study. Journal of Singing, 56:3 January, 2000, p. 71-72.

40. Estill J. Belting and Classical Voice Quality: Some Physiological Differences. Medical Problems of Performing Artists. 1988, 3, pp. 37-43.

\section{Information about authors:} Kulaha T. O.,

Postgraduate Student at the Department of Theory and Methods of Music Education and Choreography Bogdan Khmelnitsky Melitopol State Pedagogical University 20, Hetmanska str., Melitopol, Zaporizhia Region, 72300, Ukraine

Seheda N. A.,

Doctor of Education, Professor, Head of the Department of Theory and Methods of Music Education and Choreography

Bogdan Khmelnitsky Melitopol State Pedagogical University 20, Hetmanska str., Melitopol, Zaporizhia Region, 72300, Ukraine 